\title{
TEMA: INTERNETI DHE TEKNOLOGJIA NË MËSIMDHËNIE
}

\author{
Prof. Ass. Dr. Besnik HAJDARI*
}

\section{*Corresponding Author: -}

\section{HYRJE}

Gjëja më e rëndësishme në jetën humane është komunikimi. Në prehistori, njeriu në vend të ligjëratës përdorte mimikën, lëvizjet e trupit. Nevoja e njeriut për një komunikim më të mirë, bënë që të zhvillohet ligjërata. Ky ishte një hap i madh dhe i rëndësishëm në evolimin human. Më vonë kur njeriu filloi të mësojë të shkruajë, ai mundi të dërgojë mesazhe larg banesës së tij. Me zbulimin e elektricitetit, si telefoni dhe më vonë kompjuteri, sot teknologjia e komunikimit ka arritur një nivel që përveç transferimit të mesazheve, por edhe pikturave me ane të videotelefonave. Makina e shekullit XXI, kompjuteri, është gati në çdo shtëpi dhe po bëhët një mjet i nevojshëm. Posta e re elektronike, e-mail, në të cilën mund të dërgojmë edhe piktura të lëvizshme, tashmë ka zhvlehtësuar postën e letrave. Me ndihmën e sateliteve të shumtë, ne mund të realizojmë lidhje telefonike dhe video në çdo pjesë të botës. Por, teknologjia e komunikimit nuk mbaron këtu. Çdo ditë zbulohen gjëra të reja qё e bëjnë komunikimin më të lehtë.

\section{(c) $(\$)$}




\section{ÇFARË ËSHTË INTERNETI?}

Interneti është rrjet masiv që përbëhet nga rrjetet tjera, pra një infrastrukturë e rrjeteve kompjuterike. Ai lidh miliona kompjutera nga gjithë globi duke formuar një rrjet të tillë ku secili kompjuter mund të komunikojë me kompjuterin tjetër kudo në botë, me kusht që të dy janë të lidhur në internet.

Që dy kompjutera në internet të jenë në gjëndje të komunikojnë midis tyre nevojiten disa kushte:

$\varnothing$ Një kanal komunikimi (koaksial, telefonik, fibër optike, radiovale)

$\varnothing$ Një ndërfaqe që lidh kompjuterin me mjetin e transmetimit (karta e rrjetit, modemi)

$\varnothing$ Një gjuhë e përbashkët për komunikim. Në një rrjet të madh si interneti të gjithë kompjuterat duhet të përdorin të njëjtin protokoll, një bashkësi rregullash që përcaktojnë strukturën e mesazheve. Protokolli i internetit garanton transmetimin e të dhënave.

\section{PËRSE MUND TË SHFRYTEZOHET INTERNETI?}

Burim informacioni: përmes motorëve të kërkimit, faqeve web etj

Komunikim: nëpërmjet internetit mund të komunikoni me të gjithë botën me mesazhe, video konferenca, chat.

Biznes dhe marketing: nëpërmjet internetit firmat kanë mundësi të krijojnë lidhje elektronike me filialet e tyre, mund të pranojnë porosi, të ofrojnë konsulencë ose shërbime të ndryshme.

Studime dhe kërkime shkencore: pothuajse të gjitha universitetet, shkollat e larta e të tjera u vënë në dispozicion studenteve të tyre lidhje falas me internetin.

Shërbime bankare (home banking): me ndihmën e internetit ju mund të kryeni në çdo vend të botës veprime bankare

Lojra: në internet është i mundur edhe zhvillimi i lojrave të ndryshme.

\section{TIPET E KOMUNIKIMIT NË INTERNET}

Interneti është "Shtëpia e Informacionit" dhe pikërisht për ta bërë këtë informacion sa më të lehtë për tu ndarë dhe arritur është zhvilluar shkenca e komunikimit në rrjet dhe normalisht dhe mjetet e komunikimit ku do përmendim ato më të rëndësishme duke evituar rendin kronologjik të tyre.

Zines dhe EZines janë nga format më të vjetra të komunikimit derivojnë nga 'magazines' dhe janë lloj revistash online, zakonisht në formate tekst ku ndahet informacion i shkruajtur nga grupe të caktuara të cilat zakonisht nuk kanë si prirje ndarjen e madhe të informacionit por janë të drejtuar një grupi të klasifikuar lexuesish, një shembull të një faqejë të tillë mund ta shohim tek textfiles.com, zakonisht është një webserver që pret lidhje në portën 80 dhe vizitorët përdorin webbrowser (firefox, opera, safari, links etj).

\section{E-MAIL}

ose Internet Mail, edhe kjo është një nga format më të vjetra që sot njihet më shumë e zhvilluar në formën e saj web-mail si psh hotmail, yahoo-mail, apo i preferuari Gmail. Posta elektronike ose e-mail, lejon që informacioni të dërgohet midis kompjuterave dhe njerëzve në internet. Ajo është burimi më shumë i përdorur në internet. Ashtu siç, një letër që ne shkruajmë mund t'a dërgojmë në shumë adresa ashtu dhe një mesazh elektonik mund të dërgohet në një ose më shumë adresa e-mail-i.

Mailing-Lista edhe kjo një formë goxha e vjetër e komunikimit në internet. Në këtë rast kemi një program: psh GNU Mailman, tek i cili regjistrohen përdoruesit dhe komunikimi bëhët në bazë të dërgimit të email-ve, kur dërgohet një email nga një përdorues email-i i shkon të gjithë grupit, dhe nga njëra anë është goxha formë e mirë komunikimi dhe sot.

\section{IRC}

këtu kemi të bëjmë me të ashtuquajturin "chat". Kjo formë komunikimi e internetit, vjen me kanale dhe në formën e komunikimit në kohë reale midis përdoruesve duke ofruar 'kanale' në të cilat përdoruesit flasin më njëri-tjetrin në kohë reale. Chat-i në rrjet është një mënyrë të komunikuari që konsiston në dërgimin e mesazheve me tekst njerëzve që ndodhen në të njëjtën dhomë chat-i në të njëjtën kohë.

\section{WebFaqet}

kjo është forma më e përhapur sot, ku përfshihen forumet, blogjet, portalet. Në përgjithësi mund të jenë dhe faqe të veçanta ku psh mund të shkruhen vetëm letra, mund të ndahen programe apo mund të jenë faqë për zhvillime projektesh, faqe reklamuese të bizneseve të ndryshme, faqe me shërbime, faqe multimediale me video (youtube) dhe foto etj. Kjo është një kategori shumë e gjerë e cila përfshin një pjesë të mirë të asaj që nga shumica quhet 'internet' ndërkohë që në realitet është vetëm një pjesë e vogël.

\section{File Sharing (ndarja e skedarëve)}

edhe kjo është një mjet 'komunikimi', zakonisht përdoret për të ndarë informacion jo të ligjshëm ku thyhen të drejtat e autorit. Një skedar mund të dërgohet me anë të e-mail tek konsumatorët, kolegët dhe shokët në formën e shtesës ose attachment. Mund të ngarkohet në website që pastaj të mund të shkarkohet lehtë nga të tjerët.

\section{VOIP - (Voice over Internet Protocol)}

është një teknologji që ju lejon të bëni telefonata dukë përdorur lidhjet e internetit në vend të një lidhjeje telefonike (analoge). Përdorimi i VoIP është i dobishëm sepse ka kosto më të ulët dhe është më funksional se rrjetet tradicionale të telefonisë. Ju mund të merrni telefonin tuaj VoIP në një udhëtim dhe duke e lidhur atë me internetin kudo që të ndodheni do të merrni telefonata në numrin tuaj. 


\section{IM}

ose Instant MessagingIM (forma e shkurtër e "mesazheve në kohë reale - instant messaging”) është një platformë tjetër ku shkëmbehen mesazhe tekst nëpërmjet internetit. Shumë të rinj e pëlqejnë këtë mënyrë të komunikuari duke qenë se është e shpejtë dhe zhvillohet në kohë reale. Është pak a shumë si të flasësh në telefon ose ballë për ballë sepse ju e dini që personi me të cilin po komunikoni është atje dhe ju kthen përgjigje të menjëhershme.

AOL Instant Messenger (shpesh quhet dhe AIM) dhe Windows Live Messenger (i cili më parë quhej MSNMessenger) janë dy forma të shërbimeve IM më të njohura.

\section{Video Konferencat}

një tjetër formë komunikimi e ideuar për të ndarë audion dhe videon në dy drejtime në të njëjtën kohë, dhe kjo është një teknologji paksa më e komplikuar, gjithsesi. Forume diskutimi - janë ambiente të diskutimit rreth tematikave specifike, ku shkruhen mesazhe të ndryshme të cilat janë të lexueshme për cilindo. Secili mund të japë mendimin e tij publikisht ndaj këtyre mesazheve ose privatisht me e-mail.

Sot, realiteti është se të gjitha këto shërbime shumë programues po përpiqen që ti sjellin si një paketë AIO (all in one) duke u munduar të përfshijnë të gjitha shërbimet në një. Dhe shpesh i gjejmë të përziera me njëra-tjetrën.

\section{INTERNETI DHE MËSIMDHËNIA}

Qëllimi: Përdorimi i internetit në aktivitete didaktike për arritjen e objektivave pedagogjike.

Interneti ofron një mënyrë liberale të të mësuarit. Teknologjitë e reja në mësimdhënie paraqesin mjaft avantazhe. Një ndër këto është fakti që nxënësit kur janë duke punuar në kompjuter, mund të përpiqen të bëjnë një ushtrim, mund të dështojnë në fillim, por mund të rifillojnë, pa frikën e të qenit i gjykuar nga dikush, pra gjithçka është e lirë për ta.

Kompjuterat dhe aksesi në internet përmisojnë cilësinë e edukimit. Kjo lidhet me faktin që interneti shihet si një mjet $\mathrm{i}$ rëndësishëm për të gjetur burime të reja që ndihmojnë në arritjen e standarteve të reja. Mësuesit e trajtojnë internetin si një mjet kërkimi, në aktivitetet e përditshme si komunikimi me nxënësit, prindërit apo mësuesit e tjerë, ose për aktivitete organizative.

Mësuesit e përdorin internetin për të ndërtuar projekte dhe leksione të reja, për të modifikuar planet e leksioneve.

Si e përmirëson interneti proçesin e mësimdhënies?

Ju mund të përdorni internetin për të shtuar vlera, për të menaxhuar klasën tuaj ose për të përmirësuar planifikimin dhe shpërndarjen e leksioneve tuaja.

Të pajisni nxënësit me motivim:

Të lejosh nxënësit të përdorin internetin për të mësuar, ju jep një motiv për të punuar veçanërisht nxënësve që janë mërzitur me mënyrat tradicionale të shpërndarjes së informacionit, duke ndihmuar tek këta nxënës që nuk kanë interesin e duhur të asimilojnë mirë informacionin.

\section{Të zbuloni nëpërmjet pyetjeve:}

Duke përdorur internetin për aktivitete edukative sigurojmë një mënyre tjetër për të zbuluar përmes pyetjeve, dhe për vlerësim kritik të informacionit. Për t’i dhënë përgjigje pyetjeve të nxënësve mësuesi duhet të përdorë për qëllime edukative internetin. Nëse nuk e bëjmë do të ndihemi në siklet nga pyetjet e disa nxënësve.

\section{Të fitosh njohuri duke komunikuar:}

Përdorimi konstant i njohurive përmirëson të kuptuarin dhe memorien afatgjatë. Komunikimi është një mënyrë e përdorimit të njohurive. Interneti mundëson komunikim të shpejtë pavarësisht barrierave gjeografike dhe u ofron nxënësve një mundësi për të komunikuar herët në jetë me një rreze të gjërë të njerëzve.

\section{Plane leksionesh të mirë projektuara:}

Burimet dhe mundësitë për komunikim që ofron interneti ndihmojnë të hartoni plane leksionesh dhe detyra që kombinojnë zgjidhjen e problemit, shkrimin, të menduarit kritik, zbulimin dhe eksplorimin. Leksione të disenjuara në mënyrë të tillë inkurajojnë nxënësit të bëjnë pyetje, të përfshihen në proçesin e të mësuarit.

\section{Menaxhim i klasës:}

Ne mund të dërgojmë leksionet tek nxënësit, problema për detyra shtëpie, teste, nëpërmjet rrjetit duke mundësuar që nxënesit t'i aksesojnë ato nga shtëpia, bibloteka ose nga çdo vend tjetër.

Avantazhet e nxënësve që përdorin internetin për të mësuar

Më poshtë prezantohen disa faktorë të rëndësishëm se pse duhet të inkurajojmë studendët të përdorin internetin për të mësuar:

Faktori motivues

Komunikim i shpejtë

Akses në informacion

Aktivitete interaktive

Të mësuarit bashkëpunues

Materiale për kërkim shkencor 


\section{Disavantazhe të përdorimit të internetit në mësimdhënie}

Përdorimi i internetit në mësimdhënie nuk është pa probleme, disa nga problemet që ndeshen janë:

Site të papërshtatshëm.

Shkelje e privatësisë së nxënësve që mund të dëmtojë jetën e nxënësve.

Informacione të papërshtatshëm për moshën.

Kohë parapërgatitore (navigimi në Internet, shkarkimi, përshtatja e informacionit për nevojat tuaja).

Mungesë e ndërveprimit nxënës-mësues.

Përgjegjësi të reja administrative për mësuesin dhe shkollën.

\section{ÇFARË ËSHTË TIK?}

Bota karakterizohet nga ndryshime të shumta dhe të shpejta, një pjesë e të cilave ka ardhur dhe nga zhvillimi i shpejtë i teknologjisë së informacionit dhe komunikimit. Arsimi duhet t'u përshtatet ndryshimeve të vazhdueshme të teknologjisë, dhe t'i përdorë ato gjerësisht në procesin mësimor. Këtyre ndryshimeve arsimi duhet t'u përgjigjet, me ritme të shpejta, me zhvillime të brendshme sasiore e cilësore për të transmetuar njohuri e aftësi sistematike, koherente e të qëndrueshme te nxënësit, duke i reflektuar më pas këto në shoqëri për krijimin e një të ardhmeje më pozitive për të gjithë.

Në epokën e zhvillimit të teknologjisë së informimit dhe komunikimit, përdorimi i kësaj teknologjie gjatë procesit mësimor është bërë një domosdoshmëri për mësuesit. Ky zhvillim lidhet drejtpërsëdrejti me përditësimin e njohurive dhe të aftësive të reja në fushën e edukimit nga mësuesi. Teknologjia ka fuqinë dhe potencialin për të transformuar mjedisin profesional të mësimdhënies. Ajo ndikon mësimdhënien e suksesshme dhe u krijon mundësi mësuesve për të mësuar dhe bashkëpunuar me njëri-tjetrin, nëpërmjet shkëmbimit të ideve e përvojave dhe zgjidhjes së problemeve të përbashkëta pedagogjike.

Teknologjia e informacionit Shoqata e Amerikës (ITAA) e përcakton Teknologjine e informacionit si:

"Studimin, projektimin, zhvillimin, zbatimin, mbështetjen apo menaxhimin e informacionit bazë të sistemeve kompjuterike, veçanërisht aplikacionet software dhe hardwaret kompjuterike."

\section{RËNDËSIA E TIK-UT}

Para shekullit të njëzetë, tre mjetet kryesore të mësimit ishin mësuesi, teksti dhe tabela e zezë. Librat, letrat, lapsat ishin mjetet themelore për të hyrë në komunikimin dhe shkëmbimin e informacionit. Shekulli i njëzetë, solli mbizoterimin e teknologjisë në arsim.

Shumë individë do të argumentojnë se kjo është ende e vërtetë sot, por nuk mund të mohohet ndikimi në rritje i teknologjisë në arsim.

Roli i mësuesit si burimi kryesor i informimit në klasë ka ndryshuar në të mësuarit organizativ, i cili çon nxënësit apo studentët për të kërkuar informacion të pavarur. Një tipar dallues i arsimit në të gjitha nivelet në vitet e fundit është përfshirja e teknologjisë në procesin e të mësuarit.

Përdorimi i teknologjive të reja përbën një nga ndryshimet më dramatike në arsim. Kombinimi i kompjuterave dhe $\mathrm{i}$ përparësive të tjera teknologjike, si: videove me karakter didaktik, hiperteksteve e programeve të tjera përbën një aspekt reformues në fushën e arsimit. Në të gjitha vendet e botës janë bërë përpjekje të vazhdueshme për të inkorporuar arritjet teknologjike në mjedisin shkollor dhe për t'i pajisur ato me infrastrukturë informatike.

Përdorimi i teknologjisë së komunikimit dhe të informacionit gjithnjë e më shumë në të gjitha aspektet e shoqërisë, bën të rëndësishëm futjen e TIK-ut si një lëndë me rëndësi të veçantë. Kjo bën të mundur që përdorimi produktiv dhe $i$ besueshëm i TIK-ut të trajtohet si një mundësi thelbësore për jetën. Kjo lëndë përfshin jo vetëm mjeshtërinë e aftësive teknike, por edhe kuptueshmërinë për të zbatuar dhe aplikuar këto aftësi në jetën e përditshme, deri dhe në punësimin e nxënësve, menjëherë pas përfundimit të gjimnazit. TIK-u u krijon mundësi nxënësve të marrin pjesë dhe të angazhohen në shoqërinë bashkëkohore.

\section{TIK-U NË EDUKIM}

TIK nënkupton të gjitha llojet e teknologjisë, të cilat përdoren për të shfrytëzuar dhe manipuluar informacionin, pra kemi një kombinim të Teknologjisë me Informacionin dhe Komunikimin. TIK në edukim kuptohet si një implementim i pajisjeve dhe mjeteve teknologjike në procesin mësimor për të regjistruar dhe përpunuar informacionin në formë digjitale. Përdorimi i teknologjisë në shkollat tona ka ndryshuar në mënyrë të ndjeshme këto vitet e fundit. Kështu, për të pajisur nxënësit me aftësitë e nevojshme teknologjike, duhet të përdorim metoda të reja të të mësuarit në krahasim me metodat e përdorura në të mësuarit tradicional. Teknologjia dhe mjetet teknologjike janë bërë pjesë e edukimit në shkolla dhe synimi është të përdorim teknologjinë në klasa si një mjet që zhvillon dhe nxit më tej procesin e të mësuarit. Nxënësit, nga përdorimi i këtyre mjeteve të reja teknologjike kanë përfituar aftësi kompjuterike, aftësi të cilat do të mund t i përdorin në të ardhmen në vendet e tyre të punës. Shkollat në sisemin arsimor shqiptar kanë krijuar një infrastrukturë teknologjike, e cila optimizon integrimin e teknologjisë në procesin edukativ.

Përdorimi me efikasitet i teknologjive të reja që mbështet procesin e të menduarit te nxënësit, rrit aftësinë e nxënësit për t’u përqendruar në mësim, përmirëson të kuptuarit dhe transferon përmbajtjen në një memorje afatgjatë. Duke $u$ mbështetur në këtë arsyetim, është synuar t’i kthejmë klasat tradicionale në klasa të konceptuara mbi bazën e teknologjisë. Ky proces kërkon që mësuesit të pajisen me aftësitë e duhura teknologjike dhe të mësojnë të përdorin mjetet e reja teknologjike që mbështesin procesin e mësimdhënies te nxënësit dhe progresin e tyre. 
Ja disa nga teknologjitë që mësimdhënësit duhet të përdorin:

\title{
Kompjuteri:
}

Shihet si një nga teknologjitë më të nevojshme në fushën e mësimdhënies, deri para pak kohësh ai konsiderohej si një risi, tashmë ai është i domosdoshëm për shkak të orientimeve teknologjike që kanë përfshirë mësimdhënien.

USB:

Është njëra nga teknologjitë më të përparuara përsa i përket ruajtjes dhe transmetimit të informacioneve të ndryshme, ato ekzistojnë në madhësi të ndryshme dhe janë pjesë e pandashme tashmë e realitetit arsimor.

\section{CD/DVD:}

Janë mënyrat e vjetra të transmetimit dhe të ruajtjes së materialeve. Por që janë mjaft frytdhënëse në rastet e prezantimeve të ndryshme.

Aparatet fotografike dixhitale shumëfunksionale: Këto paisje kanë mjaft rëndësi në fushën e mësimdhënies së gjuhëve të huaja, pasi me anën e tyre realizohet regjistrimi dhe prezantimi i aftësive të çdonjërit nga nxënësit përsa i përket aftësimit gjuhësor.

Interneti: Është teknologjia e cila ka revolucionalizuar mësimdhënien në çdo skaj të botës. Me anën e tij, tashmë mësuesi nuk është e vetmja pikë e referimit, por është koodinatori i hyrjeve të reja në kulturën arsimore të nxënësit.

Tabela Interaktive: Është një teknologji mjaft e përparuar e cila ende nuk është futur në masë në sistemin arsimor shqiptar, por ama për shkak të thjeshtësive, risive dhe avantazheve që ajo paraqet, është mjaft e dëshiruar në dobi të punës së tij (saj) nga çdo mësimdhënës.

Video Projektori: Është një teknologji e cila gjendet mjaft në sistemin arsimor shqiptar. Me anën e tij realizohet prezantimi i punimeve të ndryshme në fushën didaktike dhe shkencore. Në të vërtetë ai është paraardhës i tabelës interaktive, por ama për vetë kushtet e sistemit tonë arsimor ai ngelet si teknologjia më e përparuar e cila përdoret në mësimdhënie.

\section{AVANTAZHET E PËRDORIMIT TË TIK NË MËSIMDHËNIE}

Fillimisht mësuesit duhet të dallojnë qartë lidhjen midis përdorimit të TIK dhe programit të mësimdhënies.

$\mathrm{Ne}$ duhet të dijmë ta përdorim teknologjine para se të mësojmë me ndihmën e saj.

Ne përdorim teknologjinë për të mësuar të njëjtat gjëra si më përpara sepse TIK na lejon që të kemi një mësimdhënie: më të lehtë, më të shpejtë, më efikas.

Shtrirje në një gamë më të gjerë materialesh njëkohësisht.

Kemi të bëjmë edhe me një barazi mbi zgjedhjet e akseset e informacioneve. Përshembull edhe nxënësit e krahinave rurale të izoluara kanë mundësi të kenë informacione mjaft të vlefshme për mësimdhënien.

\section{BENEFITET NGA SHFRYTËZIMI I KOMPJUTERIT GJATË MËSIMIT \\ Mbajtja dhe drejtimi vëmendjes}

Kompjuteri e tërheq vëmendjen me ndihmën e ngjyrave, zërave dhe fotografive interesante. Vëmendja është më e madhe para kompjuterit pasi që njohuritë fitohen përmes lojës.

Shembull: Nxënësit të cilët kanë probleme me sjelljen (nxënës hiperaktiv, nxënës me vështirësi gjatë mësimit) mund të kenë vëmendje më të gjatë para kompjuterit gjatë mësimit klasik.

\section{Kënaqësia}

Kompjuteri është burim i kënaqësisë, që paraqet faktor të rëndësishëm për sukses. Çdo detyrë e kryer me sukses për të cilën nxënësi merr lavdërime i jep vetë besim dhe e rritë dëshirën e tij për sukses.

\begin{abstract}
Autonomia
Kompjuteri lejon që të tejkalohen një pjesë të mossukseseve me të cilat zakonisht has nxënësi kur punon me mjetet shkollore. Nxënësi mund të realizojë ndonjë aktivitet në tërësi me pjesëmarrje minimale të personit të tretë, i cili do t’i ndihmojë gjatë punës me veglat.

Shembull: Nxënësi me paralizë cerebrale ka vështirësi gjatë të shkruarit me laps në fletore. Përjeton pengim dhe mossukses gjatë realizimit të këtij aktiviteti. Me ndihmën e aparateve asistive dhe kompjuterin pavarësisht shkruan, është më i shpejtë dhe i lumtur për kryerjen me sukses të aktivitetit.
\end{abstract}

\section{Përshtatshmëria}

Llojshmëria e mbështetjes dhe të veglave teknike lejon që të përshtatet vegla kompjuteristike dhe/ose përmbajtjet e nxënësve të ndryshëm.

Shembull: Aparatet e ndryshme asistive dhe softueri përshtatet ndaj nevojave, mundësive dhe interesimeve të çdo nxënësi. Nuk ekziston nxënës me nevoja të veçanta arsimore i cili nuk do të mund të përdorë kompjuter.

\section{Ndjenja e vlerësimit}

Kompjuteri ofron ndjenjë të vlerësimit dhe vetë vlerësimit të nxënësit. Ai është burim i marrjes së përgjegjësisë dhe pjesëmarrje në grup dhe kontribuon në stabilizimin e sjelljeve. 
Shembull: Nxënësi me vështirësi gjatë mësimit nuk i njeh në tërësi ngjyrat dhe format. Për këtë qëllim në orën e matematikës përdor vizatim për ngjyrosje, ku format e ndryshme duhet të ngjyrosen me ngjyra themelore. Vizatimi është ngjitur në klasë, ndërsa nxënësi është lavdëruar. Herën e ardhshme me kënaqësi i prin aktivitetit, më lehtë e kryen dhe është i kënaqur pasi që nxënësit tjerë kanë mendim pozitiv për atë.

\section{STUDIM}

Njerëzit bashkëveprojnë me mjetet teknologjike moderne dhe i përdorin ato për arsye nga më të ndryshmet. Këto dy persona që shihni në këtë pamje po komunikojnë me njëri-tjetrin. Ato po flasin dhe mund të shihen nëpëmjet Webcamerës edhe pse nuk janë pranë njëri- tjetrit fizikisht. Ato mund të jenë me mijëra e qindra kilometra larg. Pra interneti me gjithë ekipin e tij fizik (kompjuterin, webcameren, E-mail, MSN, Facebook etj.) bën të mundur lidhjen e komunikimin mes njerëzve kudo që të ndodhen qoftë brenda kufijve shqiptarë qoftë edhe jashtë tyre.

Për të parë se çfarë efekti ka teknologjia, kam vendosur që të vëzhgoj përdorim e teknologjive të reja te nxënësit e shkollës "Shote Galica", Fushë Krujë. (Zgjodha këtë shkollë pasi këtu kam mbaruar shkollën e mesme, dhe aktualisht jam mësuese e Informatikës).

\section{Pyetësori për përdorimin e teknologjive të reja:}

Shënim: Në pyetësor janë pyetur nxënësit e klasave te X(dhjeta) që janë rreth 470 nxënës.

Sa kompjutera keni në shtëpi?
Asnjë
b) $\mathrm{Një}$
c) Dy ose më shumë

Përveçse në shtëpinë tuaj, e përdorni kompjuterin në vende të tjera?
Jo
b) Po, në shkollë
c) Në qendër (Internet kafe)
d) Tek të njohurit

Ndër të gjithë nxënësit e pyetur kanë thënë se e përdorin më së shumti në shtëpi, por shpesh shkojnë edhe në Internet Kafe për veprimet e tjera të nevojshme, siç është që të printojnë, të skanojnë, të kërkojnë informacion në internet etj.

A keni internet në shtëpi?
$\begin{array}{ll}\text { Po } & \text { b) Jo }\end{array}$

Për çfarë e përdorni internetin më tepër?
Facebook
b) Kërkime shkollore
c) Për të shkarkuar muzikë
d) Për të luajtur
e) E-mail

f) Tjetër

Sa kohë keni që e përdorni Internetin ?

Në përgjithësi nxënësit e përdornin Internetin që prej 3-4 vite. Ato i ka ndihmuar shumë fakti që e kanë internetin në shkollë ku gjatë orëve të informatikës kanë mësuar si t’i përdorin programet bazë të kompiuterit, dhe nganjëherë e kanë shfrytëzuar për të hyrë në Internet.

Sa orë në ditë rrini në Internet?
1 orë
b) 2 orë
c) Më shumë
d) Asnjë orë

A ju pëlqejnë më shumë orët e mësimit kur mësuesi shpjegon në tabelë, flet e ju mbani shënime apo kur mësuesi përdor laptopin me projektor?

Të gjithë nxënësit ishin dakord kur thonin se orët e mësimit të shoqëruara me mjete teknologjike ishin më të këndshme. Me kompjuter mund të dëgjojmë qoftë këngët ose ndonjë tekst në gjuhë të huaj, me zërin e një të huaji që të mësojmë më mirë shqiptimin e saktë të fjalëve. Nxënësit gjithashtu pohojnë se orët e mësimit me projektor janë më të pëlqyerat dhe se gjatë këtyre orëve mësojnë çuditërisht shumë më lehtë. Kjo shpjegohet nga fakti se nxënësit i kushtojnë vëmendje më të madhe zërit dhe pamjes (imazhit të paraqitur nga projektori), që i ndihmon në memorizim.

\section{A e ka ndryshuar përdorimi i internetit kohën tuaj (organizimin e ditës)?}

Pjesa më e madhe e nxënësve pohon se nganjëherë kur është në internet dhe u duhet të bëjnë detyrat, e humbin sensin e kohës dhe nga kureshtja për të parë faqe të ndryshme të internetit harrohet fare dhe mund të rrijë me orë të tëra para kompjuterit pa lëvizur fare. Shpesh herë janë prindërit që i bërtasin dhe i kujtojnë që duhet të bëjnë gjëra të tjera. Disa ankohen se kanë dhimbje dhe skuqje në sy, dhe efekti tjetër mjaft problematik në kohët e fundit në të gjithë botën është se fëmijët ashtu si të rriturit nuk lëvizin më por që qëndrojnë përpara kompjuterit pa lëvizur. Kështu ato vuajnë nga problemet e mbi peshës që sjellin shumë probleme të tjera që ndikojnë negativisht në organizmin tonë.

Detyrat e ndryshme që ju japin mësuesit preferoni t`i bëni me shkrim dore apo parapëlqeni t i bëni në kompjuter? 
Pjesa më e madhe e nxënësve pohon se parapëlqejnë t’i bëjnë detyrat me kompiuter, sidomos për projektet që shërbejnë për të konkuruar mes klasave, sepse me anë të kompjuterit ato mund ta bëjnë detyrën shumë interesante. Kështu ato mund të ndryshojnë shkrimin sipas dëshirës (llojin dhe madhësinë), të nënvizojnë fjalët që duan të vënë në dukje, mund t’i bashkangjisin foto, piktura, grafikë, ngjyra, efekte të veçanta etj. Ndjejnë një kënaqësi shumë të madhe kur i prezantojnë ato në projektor para konkurentëve të tjerë, dhe ndjehen shumë krenarë kur mësuesi i lavdëron për punën e bërë, dhe sidomos për prezantimin (paraqitjen).

Ju që keni internet në shtëpi dhe që e përdorni çdo ditë, si do ndjeheshit po t’jua heqin Internetin për afro 2-3 muaj?

"Nuk arrij ta imagjinoj të rri pa internet... Mbase do shkoja në Internet Kafe, pasi interneti është bërë tashmë pjesë e jetës sime"- thotë një nxënëse.

\section{Konkluzion i pyetësorit:}

Të rinjtë e sotëm, siç vihet re edhe nga përgjigjet e pyetësorit, janë shumë të lidhur me botën e internetit. Dhe falë kurrikulës së re ato zhvillojnë si lëndë më vehte dhe kanë mundësi që jo vetëm që të mësojnë përdorimin e kompjuterit, por mund të shfrytëzojnë bazen materiale të laboratorit të informatikës dhe të punojnë për detyrat apo punimet e tyre të ndryshme që kajnë të bëjnë edhe me internetin. Kështu, nxënësit janë gjithmonë në kontakt me mjetet e reja teknologjike që do ti shërbejnë shumë edhe në të ardhmen.

Vlen të theksohet se disa nga nxënësit janë shumë të varur nga përdorimi i internetit, duke e konsideruar atë si një "virus". Gjithashtu u vu re nga përgjigjet se pjesa më e madhe e të rinjve zotëronin të paktën një kompjuter. Ajo çka është më e rëndësishme është fakti se nxënësit i pëlqejnë shumë orët e mësimit të shoqëruara me mjetet teknologjike, duke ja bërë orën më të këndëshme, dhe duke ja lehtësuar procesin e të nxënit me anë të pamjeve të ndryshme që paraqiten me kompjuter dhe video-projektor, kështu ora e mësimit bëhet më konkrete dhe më e dashur për ta.

Ja këshilloj çdo mësuesi që të integrojnë sa më shumë mjetet teknologjike në metodat e tyre të mësimdhënies.

\section{PËRFUNDIME}

Nga ky punim i bërë dalim në konkluzionin që megjithëse investimet dhe dëshira e mirë në futjen e teknologjisë në ndihmë të aktiviteteve pedagogjike, ende ekzistojnë probleme të tilla shoqërore, kulturore të cilat e zbehin nganjëherë rëndësinë e kësaj "arme" të fortë në duart e nxënësve.

\section{Nga ky punim dola në përfundimin se:}

Nevojitet një pregatitje më e mirë e mesuesve të vjetër në përdorimin e teknologjisë. Frika e të resë bën që në shume raste, eksperiencat e reja te shihen si të dyshimta nga ana e mësueve të vjetër të cilët tashmë nga vetë formimi i tyre me anën e një ideologjie dhe metodologjie pune të vjetër, por që ka qënë mjaft frytdhënëse, janë mjaft skeptikë përsa i përket futjes së teknologjisë në mësimdhënie.

Duhen kualifikuar edhe trajnues të cilët duhet të merren me aftësimin teknologjik të stafit pedagogjik, gjë e cila do të mundësonte një përdorim sa më efikas të këtyre risive teknologjike në mësimdhënie.

Në të vërtetë po propogandohet shumë teknologjia në mësimdhënie, por ama ka ca raste, siç e përmendëm edhe më lart, që teknologjia mund të shihet si një mjet i cili e dëmton procesin mësimor.

Ka mësues të cilët të nisur nga dëshira përsonale për të sjellë risi në mësimdhënien në vendin tonë, i kushtojnë një rëndësi më të madhe se duhet teknologjisë, duke shpënë vërtet në atë që ne quajmë “zevëndësim të mësuesit” nga teknologjia, pra me këto veprime ato vënë në dyshim statusin dhe rolin e mësuesit në arsimimin e brezave të ri.

Por ama vërtet që edhe programet ekonomiko-orientuese të ndërmarra në favor të informatizimit të sistemit arsimor kanë dhënë mundësinë që tani mësimdhënia të jetë më atraktive dhe tashmë të kemi një bashkëpunim paralel mes mësuesit dhe nxënësit duke ju shmangur asaj metodës së vjetër të bashkëpunimit të tërthortë, ku mësuesi ishte i vetmi mjet informacioni dhe shpeshherë kthehej në rolin e një cicëroni që transmetonte thjesht materialin pedagogjik pa i dhënë hapësirë përdorimit të prakticitetit në mësimdhënie

\section{Literatura}

[1] Material nga libri: Teknologjia e informacionit dhe komunikimit në shkolla,

[2] Autorët: Eva Cipi, Alketa Hyso, Dezdemona Gjylapi, Eljona Proko, Mejola Kodra Tiranë 2012,/ 